\title{
Identification and Characterization of Staphylococcus Isolates in Fes- Meknes Region in Morocco
}

\author{
EL Malki Fatima1, EL Lekhlifi Zineb² and Barrijal Said²*
}

${ }^{1}$ Institut Pasteur du Maroc of Tangier, Morocco

${ }^{2}$ Faculty of Sciences and Techniques, Tangier, Morocco

\begin{abstract}
Staphylococci are among the most commonly recovered bacteria in the clinical microbiology laboratories According to the coagulase test, staphylococci are categorized as $S$. aureus and coagulase negative staphylococci (CoNS). Although S. aureus is more virulent, CoNS may also cause infections, some of which may be lifethreatening. Raising staphylococci multi-drogue resistance has complicated therapeutic protocols especially for $S$. aureus resistant to meticillin (SARM). In our study we characterized by phenotypic and molecular data, a group of staphylococci collected from hospital laboratories. Comparison between standard laboratories procedures in routine identification and molecular methods showed a good correlation of both. Multiplex-PCR revealed that all species specific 16S RNA positive were coagulase positive and identified to be $S$. aureus. Besides, all mecA positive isolates were cefoxitin resistant. The prevalence of SARM was found $11.76 \%$ while meticillin resistant coagulase negative staphylococcus (MRCoNS) was $84.61 \%$.

Although the analyzed staphylococcal isolates sample is small, our study revealed a relatively low prevalence of SARM in this region of Morocco compared to others region of the world. The very high prevalence of MRCoNS isolates is alarming and demonstrating that CoNS are becoming the main source for dissemination of mecA gene.
\end{abstract}

Keywords: Staphylococcus aureus; CoNS; SARM; Multiplex-PCR; mecA

\section{Introduction}

Staphylococcus genus currently consists of 38 species [1]. S. aureus is the most important pathogen and the most virulent wile $S$. epidermidis and other coagulase negative Staphylococci (CoNS) are commensally common flora of skin and mucous membranes and are therefore common contaminants, particularly in blood cultures. However, increased incidence of infections caused by CoNS has been reported [2]. These bacteria have also become an important cause of hospitalacquired infections [3]. Discrimination between $S$. aureus and others CoNS in clinical samples is important to evaluate the virulence level. Moreover, rising Staphylococcus isolates multi-resistant to antibiotics has complicated the antimicrobial therapeutic scheme.

Hospital infections due to methicillin-resistant Staphylococcus aureus (MRSA) strains are frequent worldwide [4]. In fact, MRSA is considered as a serious threat to hospitalized patients and is becoming a challenge for public health. Moreover, MRSA community-acquired infections appear to be on the increase in various part of the world [5]. The consequences to the health care system are graves with longer hospitalization, greater costs in addition to higher mortality and morbidity rates due to invasive MRSA infection [6].

Thus, rapid and reliable detection and identification tests is an important infection control policy method and might help the clinician to reduce the use of inappropriate therapy, preventing the dissemination of this microorganism.

In Morocco few data are available concerning the MRSA frequency in hospitals or community. This study aims to assess the MRSA frequency in the central region of Morocco comparing the standard phenotypic methods and PCR method to differentiate $S$. aureus from CoNS.

\section{Material and Methods}

\section{Bacterial isolates}

One hundred forty one isolates, among them sixty two Staphylococcus, were collected from hospital bacteriological laboratories in Fes-Meknes region during a period of three months (1st July to 30th September 2010).

\section{Identification of staphylococcal isolates}

The isolates were identified morphologically and biochemically by standard laboratory procedures. The coagulase plasma test was performed on organisms exhibiting typical Staphylococcal colony morphology to allow discrimination of $S$. aureus from coagulatenegative Staphylococci [7].

\section{Staphylococcus antibiotic susceptibility testing}

Resistance to $\beta$-lactams (including methicillin) is assessed by Cefoxitin disk (FOX $30 \mu \mathrm{g}$ ). In addition, susceptibility to fourteen other antibiotics were determined by the agar disk diffusion method. Antibiotics tested are listed: cefoxitin (FOX), vancomycin (VA), teicoplanin (TEC), amikacin (AN), tobramycin(TM), netilmecin(NET), erythromycin (E), lincomycin (L), tertacyclin (TE), chloramphenicol (C), ciprofloxacin (CIP), rifampecin (RA), corticomoxasol (SXT), fosfomycin ( FOS), fusidic acid (FA) [8].

${ }^{*}$ Corresponding author: Barrijal Said, Faculty of Sciences and Techniques Tangier, Morocco, E-mail: barrijal@yahoo.fr

Received March 16, 2012; Accepted March 29, 2012; Published March 31, 2012

Citation: Malki Fatima EL, Lekhlifi Zineb EL, Said B (2012) Identification and Characterization of Staphylococcus Isolates in Fes-Meknes Region in Morocco. Pharm Anal Acta S15. doi:10.4172/2153-2435.S15-003

Copyright: (C) 2012 Kummalue T. This is an open-access article distributed unde the terms of the Creative Commons Attribution License, which permits unrestricted use, distribution, and reproduction in any medium, provided the original author and source are credited. 
Citation: Malki Fatima EL, Lekhlifi Zineb EL, Said B (2012) Identification and Characterization of Staphylococcus Isolates in Fes-Meknes Region in Morocco. Pharm Anal Acta S15. doi:10.4172/2153-2435.S15-003

Page 2 of 4

\section{DNA extraction and polymerase chain reaction (PCR)}

Staphylococcal colonies were emulsified in $100 \mu \mathrm{l}$ sterile distilled water to produce a heavy suspension, and heated at $100^{\circ} \mathrm{C}$ for $15 \mathrm{~min}$, then centrifuged at $12.000 \mathrm{rpm}$ for $10 \mathrm{~min}$.

Multiplex-PCR was performed to detect mecA gene and S. aureus 16S RNA using the reported primers [9].

\section{Result and Discussion}

\section{Bacterial isolates and identification}

During a period of three months (from July to September 2010) 241 isolates were collected from hospital laboratories of Fes-Meknes region and routinely identified by standard laboratory procedures. We focused our analysis on Staphylococcus group as they occupy the second place, just after Enterobacteriaceae with more than 25\%, in

\begin{tabular}{|c|c|c|}
\hline Isolates & no & $\%$ \\
\hline E. coli & 97 & 40.24 \\
\hline Staphylocoques & 62 & 25.73 \\
\hline Klebsiella & 40 & 16.60 \\
\hline Pseudomonas & 11 & 4.56 \\
\hline Streptocoque & 8 & 3.32 \\
\hline Acinetobacter & 5 & 2.13 \\
\hline Proteus & 5 & 2.07 \\
\hline Enterobacter & 4 & 1.66 \\
\hline Enterocoque & 3 & 1.24 \\
\hline Bacillus & 1 & 0.41 \\
\hline Providencia & 1 & 0.41 \\
\hline Listeria & 1 & 0.41 \\
\hline Salmonella typhi & 1 & 0.41 \\
\hline Citrobacter & 1 & 0.41 \\
\hline Morganella & 1 & 0.41 \\
\hline Total & 241 & 100 \\
\hline
\end{tabular}

Table 1: Percentage of different isolates.

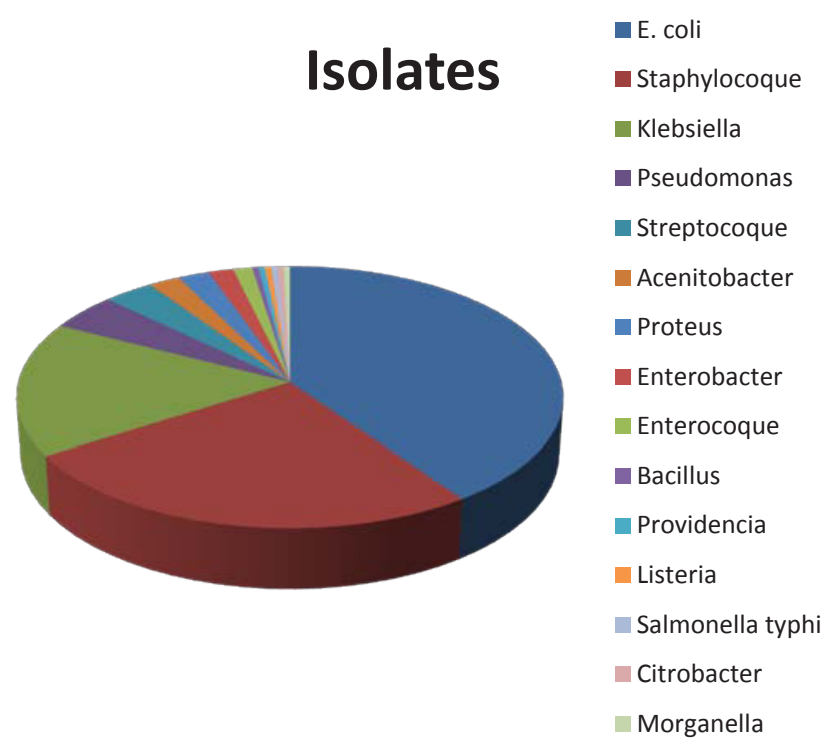

Figure 1: Representation of total collected bacterial isolates.

\begin{tabular}{|c|c|c|}
\hline Samples & no & $\%$ \\
\hline Pus & 22 & 35.48 \\
\hline Urinary & 19 & 30.64 \\
\hline Blood & 10 & 16.13 \\
\hline Urethral & 4 & 6.45 \\
\hline Vaginal & 1 & 1.61 \\
\hline Undetermined & 6 & 9.68 \\
\hline Total & 62 & 100 \\
\hline
\end{tabular}

Table 2: Percentage of samples.

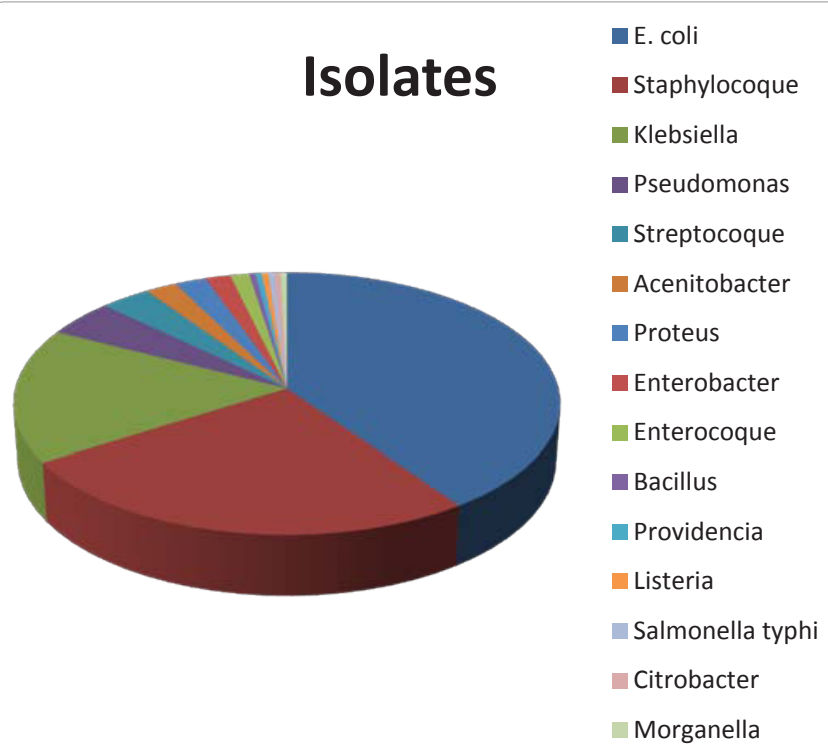

Figure 2: Representation of total collected bacterial isolates.

routinely isolated bacteria from different infection diseases (Table 1 and Figure 1).

\section{Distribution of staphylococcal samples}

We examined sixty two gram-positive bacteria isolated from different type of human physiological liquid. As showed in table 2, Staphylococcus bacteria can be isolated from various kinds of human fluid demonstrating its ubiquitous localization. The pus secretions are the most affected (35.48\%) followed by urinary samples $(30.64 \%)$ shown in Figure 2.

\section{Antibiotic susceptibility}

Fifteen different antibiotics were tested. Staphylococcus isolates susceptibility rates are showed in table 3 . Resistance to cefoxitin is over $36 \%$. The higher rate is detected for tetracyclin (46\%) followed by erythromycin (40\%) and fusidic acid (33\%). The lower resistance rate was reported for amikacin and chloramphenicol (3\%) wile lincomycin exhibited $100 \%$ susceptibility. For vancomycin and teicoplanin apparent resistance was detected by agar disc diffusion method. The CMI test for vancomycin has been carried out, and these isolate were classed vancomycin susceptible with CMIs of $1 \mathrm{mg} / \mathrm{L}$ or $0.5 \mathrm{mg} / \mathrm{L}$. revealing their sensitivity (Table 4). 
Citation: Malki Fatima EL, Lekhlifi Zineb EL, Said B (2012) Identification and Characterization of Staphylococcus Isolates in Fes-Meknes Region in Morocco. Pharm Anal Acta S15. doi:10.4172/2153-2435.S15-003

Page 3 of 4

\begin{tabular}{|c|c|c|c|c|c|}
\hline \multirow{2}{*}{ Antibiotics } & \multicolumn{2}{|c|}{$\mathrm{R}$} & \multirow{2}{*}{$\begin{array}{c}\mathrm{I} \\
\mathrm{Nbr}\end{array}$} & \multicolumn{2}{|c|}{ S } \\
\hline & $\mathrm{Nbr}$ & $\%$ & & $\mathrm{Nbr}$ & $\%$ \\
\hline FOX & 11 & 36.67 & 1 & 18 & 60 \\
\hline VA & 6 & 20 & 5 & 19 & 63.33 \\
\hline TEC & 8 & 26.67 & 6 & 16 & 30 \\
\hline AN & 1 & 3.33 & 0 & 29 & 96.67 \\
\hline TM & 6 & 20 & 0 & 24 & 80 \\
\hline NET & 1 & 3.33 & 0 & 29 & 96.67 \\
\hline E & 12 & 40 & 0 & 18 & 60 \\
\hline L & 0 & 0 & 0 & 30 & 100 \\
\hline TE & 14 & 46.67 & 0 & 16 & 30 \\
\hline C & 1 & 3.33 & 0 & 29 & 96.67 \\
\hline CIP & 9 & 30 & 0 & 21 & 70 \\
\hline RA & 6 & 20 & 0 & 24 & 80 \\
\hline SXT & 5 & 16.67 & 0 & 25 & 83.33 \\
\hline FOS & 5 & 16.67 & 2 & 23 & 76.67 \\
\hline FA & 10 & 33.33 & 0 & 20 & 66.67 \\
\hline
\end{tabular}

Table 3: Antibiotics susceptibility of Staphylococci isolated.

\begin{tabular}{|c|c|c|c|c|c|c|c|c|c|c|}
\hline \multicolumn{11}{|c|}{ Tableau: Resultat de CMI } \\
\hline Isolat [] & 64 & 32 & 16 & 8 & 4 & 2 & 1 & 0.5 & 0.25 & 0 \\
\hline $61 Z$ & - & - & - & - & - & - & - & + & + & + \\
\hline $92 Z$ & - & - & - & - & - & - & - & + & + & + \\
\hline $97 Z$ & - & - & - & - & - & - & + & + & + & + \\
\hline $101 Z$ & - & - & - & - & - & - & + & + & + & + \\
\hline $103 Z$ & - & - & - & - & - & - & - & + & + & + \\
\hline $90 \mathrm{M}$ & - & - & - & - & - & - & - & + & + & + \\
\hline $93 \mathrm{M}$ & - & - & - & - & - & - & - & + & + & + \\
\hline $98 \mathrm{M}$ & - & - & - & - & - & - & - & + & + & + \\
\hline $99 \mathrm{M}$ & - & - & - & - & - & - & - & + & + & + \\
\hline
\end{tabular}

Table 4: CMI Determination for vancomycin.

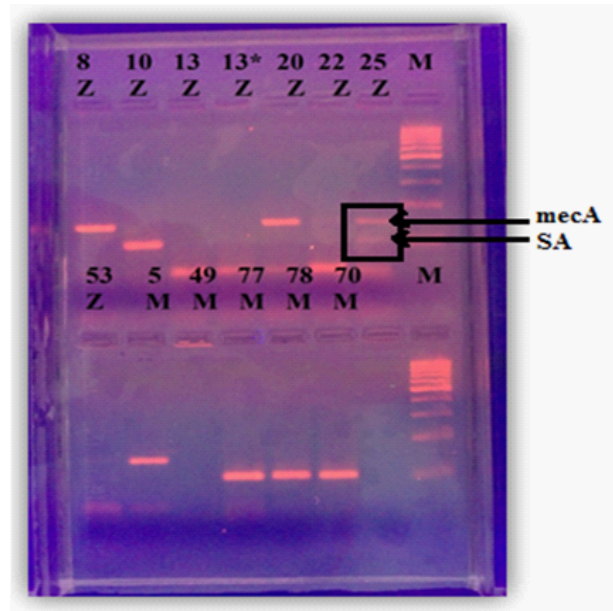

Figure 3: Agarose gel electrophoresis of amplified DNA corresponding to the S. aureus species specific segment $(S A=108 \mathrm{bp})$ and the mecA gene $(154$ bp) detected by the multiplex PCR.

\section{PCR detection of mecA gene and 16S RNA}

A sub-site of 30 Staphylococcus isolates were selected on the basis of their antibiotic resistance profiles to be further characterized by multiplex-PCR to assess the presence of $m e c A$ gene and $S$. aureus 16S-RNA to confirm the MRSA strains. A sample of multiplex-PCR products are shown by Figure 3. The two genes are detected in 25 isolates and which is then a MRSA. Others isolates presenting only one segment are mecA positive (case of meticillin resistant CoNS) or $S$. aureus meticillin sensitive (SAMS).

\section{Conclusion}

The obtained results were compared with coagulase test and the cefoxitin susceptibility. These two tests are used in routine procedures to identify MRSA.

Among the 30 Staphylococcus 17 were coagulase positive and then considered as $S$. aureus strain and the remained 13 isolates were belonging to CoNS group. Eleven isolates were resistant to cefoxitin $(\Phi \leq 24 \mathrm{~mm})$ and one was an intermediary phenotype $(\Phi=25 \mathrm{~mm})$. 
Citation: Malki Fatima EL, Lekhlifi Zineb EL, Said B (2012) Identification and Characterization of Staphylococcus Isolates in Fes-Meknes Region in Morocco. Pharm Anal Acta S15. doi:10.4172/2153-2435.S15-003

S. aureus 16S RNA was detected by PCR in 17 isolates which is in correlation with the coagulase test $[10,11] . m e c A$ gene was detected in 13 isolates only two among them showed S. aureus species specific segment, and then are MRSA strains. Hence, the frequency of $m e c A$ gene in S.aureus estimated at $11.76 \%$ is relatively low $(2 / 17)$ compared to CoNS group which showed very high prevalence with $84.61 \%(11 / 13)$. The CoNS isolates are becoming the main source for dissemination of mecA gene.

Although the analyzed Staphylococcal isolates sample is small, our study revealed a relatively low prevalence of SARM in this region of Morocco compared to others region of the world [12].

\section{References}

1. Kleeman KT, Bannerman TL, Kloos WE (1993) Species distribution of coagulase-negative staphylococcal isolates at a community hospital and implications for selection of staphylococcal identification procedures. J Clin Microbiol 31: 1318-1321.

2. Edwards KJ, Kaufmann ME, Saunders NA (2001) Rapid and accurate identification of coagulase-negative staphylococci by real-time PCR. J Clin Microbiol 39: 3047-3051.

3. Mekontso-Dessap A, Kirsch M, Vermes E, Brun-Buisson C, Loisance D, et al. (2002) Nosocomial infections occurring during receipt of circulatory support with the paracorporeal ventricular assist system. Clin Infect Dis 35: 1308-1315.

4. Oliveira DC, Tomasz A, de Lencastre H (2002) Secrets of success of a human pathogen: Molecular evolution of pandemic clones of meticillin-resistant
Staphylococcus aureus. Lancet Infect Dis 2: 180-189.

5. Vandenesch F, Naimi T, Enright MC, Lina G, Nimmo GR, et al. (2003) Community-acquired methicillin-resistant Staphylococcus aureus carrying Panton-Valentine leukocidin genes: worldwide emergence. Emerg Infect Dis 9: 978-984.

6. Lodise TP, McKinnon PS (2005) Clinical and economic impact of methicillin resistance in patients with Staphylococcus aureus bacteremia. Diagn Microbiol Infect Dis 52: 113-122.

7. Murray PR (2003) Manual of clinical microbiology. (8thedn), American Society for Microbiology Press, Washington, DC, USA.

8. Lalitha MK (2004) Manual on Antimicrobial Susceptibility Testing (Under the auspices of Indian Association of Medical Microbiologists).

9. Schuenck RP, Lourenco MC, lório NL, Ferreira AL, Nouér SA, et al. (2006) Improved and rapid detection of methicillin-resistant Staphylococcus aureus nasal carriage using selective broth and multiplex PCR. Res Microbiol 157 971-975.

10. Jones RN, Nilius AM, Akinlade BK, Deshpande LM, Notario GF (2007) Molecular characterization of Staphylococcus aureus isolates from a 2005 clinical trial of uncomplicated skin and skin structure infections. Antimicrob Agents Chemother 51: 3381-3384.

11. Maltezou HC, Giamarellou H (2006) community-acquired methicillin-resistant Staphylococcus aureus infections. Int J Antimicrob Agents 27: 87-96.

12. Krishnan PU, Miles K, Shetty N (2002) Detection of methicillin and mupirocin resistance in Staphylococcus aureus isolates using conventional and molecular methods: a descriptive study from a burns unit with high prevalence of MRSA J Clin Pathol 55: 745-748. 